\title{
The solution structure of a $3^{\prime}$-phenazinium $(\mathrm{Pzn})$ tethered DNA - RNA duplex with a dangling adenosine: $r\left(5^{\prime} G-\right.$ AUUGAA3'):d(5'TCAATC3' - PZn)
}

\author{
T.V.Maltseva, P.Agback, M.N.Repkova1', A.G.Venyaminova1', E.M.Ivanova1', A.Sandström, \\ V.F.Zarytova ${ }^{1}$ and J.Chattopadhyaya* \\ Department of Bioorganic Chemistry, Box 581, Biomedical Center, University of Uppsala, S-751 23 \\ Uppsala, Sweden and ${ }^{1}$ Institute of Bioorganic Chemistry, Siberian Branch of the Russian Academy of \\ Sciences, Novosibirsk 630090, Russia
}

Received September 24, 1994; Revised and Accepted October 20, 1994

\begin{abstract}
The $3^{\prime}$-Pzn group tethered to an oligo-DNA stabilizes a DNA-RNA hybrid duplex structure by $13^{\circ} \mathrm{C}$ compared to the natural counterpart. This report constitutes the first full study of the conformational features of a hybrid DNA - RNA duplex, which has been possible because of the unique stabilization of this rather small duplex by the tethered $3^{\prime}$-Pzn moiety $\left(T_{\mathrm{m}}\right.$ $\approx 40^{\circ} \mathrm{C}$ from NMR). In this study, a total of 252 interand intra-strand torsional and distance constraints along with the full NOE relaxation matrix, taking into account the exchange process of imino and amino protons with water, have been used. The 3'-Pznpromoted stabilization of the DNA - RNA hybrid duplex results in detailed local conformational characteristics such as the torsion angles of the backbone and sugar moieties that are close to the features of the other natural DNA - RNA hybrids (i.e. sugars of the RNA strand are 3'-endo, but the sugars of the DNA strand are intermediate between A- and B-forms of DNA, $72^{\circ}$ $<P<180^{\circ}$; note however, that the sugars of our DNA strand have a $\mathrm{C}_{1}$-exo conformation: $131^{\circ}<P<$ $\left.154^{\circ}\right)$. This study suggests that $3^{\prime}-$ Pzn-tethered smaller oligo-DNA should serve the same purpose as a larger oligo-DNA as a antisense inhibitor of the viral mRNA. Additionally, these types of tethered oligos have been found to be relatively more resistant to the cellular nuclease. Moreover, they are taken up quite readily through the cellular membrane (14) compared to the natural counterparts.
\end{abstract}

\section{INTRODUCTION}

Ribonucleic acids (RNAs) play a wide range of important roles in living cells, including the traditional roles in transcription and translation (tRNA, mRNA and rRNA) of genetic information. Excitement in RNA chemistry has also grown with the discovery of RNA sequences with catalytic activity, the formation of 'lariats' during the processing of pre-RNA, and the development of recombinant RNA technology. In addition, it has been found that many families of retroviruses, including the HIV retrovirus, use RNA to carry the genetic material to the infected host cells. The reverse transcription of the viral RNA by the viral reverse transcriptase gives the DNA - RNA hybrids which are specifically degraded by the inherent $\mathrm{RNase} \mathrm{H}$ activity of the viral reverse transcriptase giving proviral DNA that then finally becomes integrated into the host DNA. Thus the inhibition of any of the above key processes will be able to suppress the activity of retroviral polymerases and thus viral replication. The binding of DNA ligands such as intercalators or minor groove binding ligands have been studied and reviewed extensively (1). Recently, an attempt to design an RNA - DNA hybrid binding agent has been partly successful (2). It has been known for some time now that a covalently linked agent $(5 \mathrm{~h})$ such as cholesterol (3), ethidium bromide (4), acridine $(5 a-c)$ or phenazinium (Pzn) $(6 a)$ derivative stabilizes the DNA duplex considerably in comparison with their natural counterparts. Most of the conclusions of these studies are based upon UV spectrometric data, except for a few NMR studies with acridine $(5 \mathrm{~d}-\mathrm{g})$ and Pzn $(6 \mathrm{~b}-\mathrm{g})$. Only recently have we begun to understand the mechanism of stabilization with our $5^{\prime}$-Pzn-tethered matched and mismatched duplex $(6 b, c)$. We showed (6b) that the Pzn tether increases the thermodynamic stability of the duplex by $9-20^{\circ} \mathrm{C}$, compared with the natural counterparts, this stability however decreases as the number of mismatches increases with the target DNA sequence. In addition, we found that the Pzn-mediated stabilization of the DNA duplex depends both on the stacking ability (6b) with the neighbouring nucleobases in both strands as well as on the hydration pattern in the minor and the major grooves of DNA (6c). Interestingly, we found (6c) by comparing the extent of hydration (by NOESY and ROESY experiments) in matched and single-mismatched DNA duplexes with or without the Pzn tether that the amount of hydration decreases as the $T_{\mathrm{m}}$

*To whom correspondence should be addressed 
stability of the Pzn-tethered DNA duplex increases compared to the non-tethered counterpart. These studies have led us to address the question if it is possible to stabilize an otherwise unstable small DNA - RNA hybrid duplex by using 3'-Pzn-tethered DNA. We here report our high-resolution NMR studies in combination with the MD/MARDIGRAS refinement procedure to determine the conformational properties of the 3'-Pzn-tethered DNA-RNA hybrid, r(5'GAUUGAA3'):d(5'TCAATC3' - Pzn), which is $13^{\circ} \mathrm{C}$ more stable (Fig. 1A) than the natural counterpart without the Pzn tether.

\section{MATERIALS AND METHODS}

\section{Synthesis and sample preparation}

Oligonucleotide 5'r(GAUUGAA)3' was synthesized according to the standard $\mathrm{H}$-phosphonate methodology (7) using a manual preparative solid phase synthesis (8a) protocol $(400 \mathrm{mg}$ of nucleoside-bound CPG with loading of $50 \mu \mathrm{mol} / \mathrm{g}$ ). Preparative purification of the 5'r(GAUUGAA)3' was carried out by successive anion-exchange HPLC [Polysil CA (8b) $(4.6 \times 250$ $\mathrm{mm}), 3 \mathrm{M} \mathrm{KH}_{2} \mathrm{PO}_{4}$ in $30 \%$ acetonitrile] and reverse phase HPLC [Lichrosorb RP-18 $(4.6 \times 250 \mathrm{~mm}), 0-20 \%$ acetonitrile containing $\left.0.05 \mathrm{M} \mathrm{LiClO}_{4}\right]$. Oligonucleotide was isolated as lithium salt (300 $\mathrm{OD}_{260}$ units).

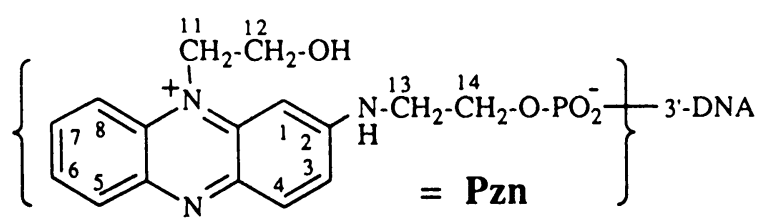

5'p[d(TCAATC)]3'-Pzn was synthesized by using a standard protocol $(8 \mathrm{c})$ and isolated by anion-exchange and reverse phase HPLC as described above. For NMR measurements, the oligonucleotides were purified additionally by successive passage through a small column of Dowex $50\left(\mathrm{Na}^{+}\right)$and Chelex 100 $\left(\mathrm{Na}^{+}\right)$resins. The NMR sample was dissolved in $0.4 \mathrm{ml}$ of the buffer $\left(0.1 \mathrm{M} \mathrm{NaCl}, 10 \mathrm{mM}, \mathrm{NaH}_{2} \mathrm{PO}_{4}, 10 \mathrm{mM}\right.$ EDTA, $\mathrm{pH}$ 7.4) and twice lyophilized to dryness from $\mathrm{D}_{2} \mathrm{O}$ and dissolved in $\mathrm{D}_{2} \mathrm{O}(99.96 \% \mathrm{D})$. The duplex, $\left\{5^{\prime} r\left(\mathrm{G}^{1} \mathrm{~A}^{2} \mathrm{U}^{3} \mathrm{U}^{4} \mathrm{G}^{5} \mathrm{~A}^{6} \mathrm{~A}^{7}\right) 3^{\prime}: 5\right.$ 'p $\left.\left[d\left(T^{8} C^{9} A^{10} A^{11} T^{12} C^{13}\right)\right] 3^{\prime}-P z n\right\}$, concentration for NMR measurements was $10 \mathrm{mM}$ and $25 \mu \mathrm{mM}$ for the UV measurement. Molar extinction coefficients of 5'r(GAUUGAA)3' and 5'p[d(TCAATC) $] 3^{\prime}-$ Pzn were estimated (8d) at $260 \mathrm{~mm}$ ( $\epsilon=77900 \mathrm{M}^{-1} \mathrm{~cm}^{-1}$ and $56900 \mathrm{M}^{-1} \mathrm{~cm}^{-1}$, respectively).

\section{Nuclear magnetic resonance spectroscopy}

${ }^{1} \mathrm{H}-\mathrm{NMR}$ spectra were recorded on a Bruker AMX NMR spectrometer operating at 500.13 MHz. NOESY experiments in $\mathrm{D}_{2} \mathrm{O}$ at $12^{\circ} \mathrm{C}$ (with mixing times of $5 \mu \mathrm{s}$ and $150 \mathrm{~ms}$ ) and in $90 \% \mathrm{H}_{2} \mathrm{O}-10 \% \mathrm{D}_{2} \mathrm{O}$ mixture $(6 \mathrm{c})$ at $0^{\circ} \mathrm{C}$ (with A mixing time of $200 \mathrm{~ms}$ ), respectively, have been performed with a final spectra of $2000 \times 2000$ real data points after Fourier transformation. After Fourier transformation the spectra in $90 \% \mathrm{H}_{2} \mathrm{O}-10 \% \mathrm{D}_{2} \mathrm{O}$ were corrected for the excitation profile $(6 \mathrm{c})$. The volumes of all crosspeaks of all NOESY experiments were calculated and normalized using the volumes of the diagonal peaks of the $5 \mu \mathrm{s}$ NOESY (in $\mathrm{D}_{2} \mathrm{O}$ ) using the AURELIA (9a) program supplied by Bruker. DQF-COSY spectra were recorded with and without phosphorus decoupling at $12^{\circ} \mathrm{C}$. The crosspeaks were then simulated using SMART (9a). In all NOESY and DQF-COSY experiments a relaxation delay of $5 \mathrm{~s}$ was used. The $T_{1}$ was measured both by the inversion recovery and saturation recovery methods, the $T_{2}$ was measured by using the cpmg pulse sequence $(9 \mathrm{~b})$. In all cases, a $20 \mathrm{~s}$ relaxation delay was used. Correlation times $\left(\tau_{\mathrm{c}}\right)$ were calculated by two different ways: (i) using the intensity of the reference $\mathrm{H} 5-\mathrm{H} 6$ protons of $\mathrm{U}^{3}, \mathrm{U}^{4}$, $\mathrm{C}^{9}$ and $\mathrm{C}^{13}$ and of the $\mathrm{H} 2^{\prime}-\mathrm{H} 2^{\prime}$ crosspeaks of the DNA strand, assuming isotropic motion, which have been normalized to the corresponding intensity of the diagonal peaks (9a), and (ii) also by using the dipolar relaxation times $T_{1}$ and $T_{2}$, which are related for an isolated homonuclear two-spin system (10) at 12 and $0^{\circ} \mathrm{C}$. Thus, $\tau_{\mathrm{c}}$ for the $\mathrm{H} 5-\mathrm{H} 6$ and $\mathrm{H} 2^{\prime}-\mathrm{H} 2^{\prime}$ crosspeaks in DNA or RNA were $2.0 \mathrm{~ns}$ at $12^{\circ} \mathrm{C}$, whereas $\tau_{\mathrm{c}}$ at $0^{\circ} \mathrm{C}$ for $\mathrm{H} 2 \mathrm{~A}$ and the amino protons of $\mathrm{A}$ and $\mathrm{C}$ were found to be $5 \mathrm{~ns}$ and $0.8 \mathrm{~ns}$ for the $\mathrm{H} 2^{\prime}-\mathrm{H} 2^{\prime}$ crosspeaks. Note that the shorter $\tau_{\mathrm{c}}$ for the $\mathrm{H} 2^{\prime}-\mathrm{H} 2^{\prime}$ crosspeaks at $0^{\circ} \mathrm{C}$ was due to the spin diffusion (10).

\section{Model building and molecular mechanics/dynamics calculation}

The starting Cartesian coordinates of the duplexes were generated using Amber 4.0 from Arnott A-RNA and B-DNA coordinates because of the qualitative similarilty of our NMR data in the hybrid DNA - RNA in which the RNA strand showed similarity to A-type RNA and the DNA strand to the B-type DNA; one of the strands was thereafter changed to DNA or RNA, respectively, and the parameters of the Pzn residue (6b) were added to the Amber 4.0 force-field. To correct for spin diffusion of the NOESY volumes the hybrid matrix procedure of MARDIGRAS (ver. 5.0) (10) was used in which crosspeaks involving exchangeable imino and amino protons were included. The rates of exchange of imino or amino protons were calculated from the combination (6d) of NOESY and ROESY spectra in $\mathrm{H}_{2} \mathrm{O}-\mathrm{D}_{2} \mathrm{O}(9: 1 \mathrm{v} / \mathrm{v})$ at $0^{\circ} \mathrm{C}$. For MARDIGRAS runs we used isotropic single experimentally derived $\tau_{\mathrm{c}}$ of $2 \mathrm{~ns}$ for all the base protons and sugar protons at $12^{\circ} \mathrm{C}$, whereas we used $\tau_{\mathrm{c}}$ of $2 \mathrm{~ns}$ for base protons, $0.8 \mathrm{~ns}$ for the sugar protons and $5 \mathrm{~ns}$ for $\mathrm{H} 2 \mathrm{~A}$ and the amino protons of $\mathrm{A}$ and $\mathrm{C}$ at $0^{\circ} \mathrm{C}$ to obtain the effective correlation time $\left(\tau_{\mathrm{c}}{ }^{*}\right)(10,11 \mathrm{n})$ for any two-proton dipole-dipole interaction: $\tau_{\mathrm{c}}{ }^{*}=\left\{1 / 2\left[\left(1 / \tau_{\mathrm{ci}}\right)+\left(1 / \tau_{\mathrm{cj}}\right)\right]\right\}^{-1}$ where $\tau_{\mathrm{ci}}$ or $\tau_{\mathrm{cj}}$ are the correlation times of the $\mathrm{i}$ and $\mathrm{j}$ protons. Subsequently, the results were combined and averaged by AVGMARD (10) for all interproton distances using the NOESY spectra in $\mathrm{H}_{2} \mathrm{O}-\mathrm{D}_{2} \mathrm{O}(9: 1 \mathrm{v} / \mathrm{v})$ at $0^{\circ} \mathrm{C}$ and in $\mathrm{D}_{2} \mathrm{O}$ at $12^{\circ} \mathrm{C}$ at the mixing times 200 and $150 \mathrm{~ms}$, respectively, in order to cover the conformational space at a temperature range from 0 to $12^{\circ} \mathrm{C}$, which is still much below the $T_{\mathrm{m}}$ of the duplex $\left(40^{\circ} \mathrm{C}\right)$. The results were used as an input in our MD calculations. In our 7-step protocol of MD calculations (6b), we used 105 intra-residual NOEs, 55 sequential NOEs, 24 cross-strand NOEs and 7 NOEs between Pzn to duplex as distance constraints (a total of 191 NOE constraints). In addition, we have employed 6 constraints defining the Watson-Crick base pairing $(1.93 \pm 0.3 \AA)$ of the duplex and 55 torsional angle constraints from DQF-COSY experiments (an average of 17.2 constraints per nucleotide residue). Eight hybrid DNA - RNA structures represent two families of starting models: the first is based on A-type RNA in both strands, and the second is based on B-type DNA models also in both strands. Each of this family has 4 structures $(q 1-q 4)$ encompassing four different stereochemical orientations of the Pzn residue (see the footnote to Table 4). 
(A)

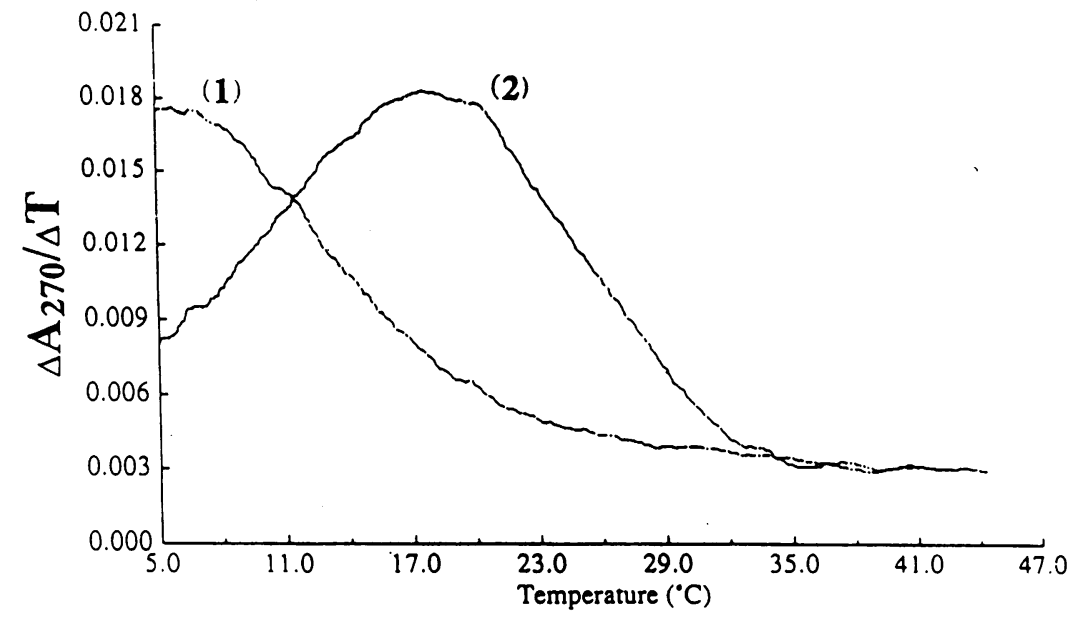

(B)

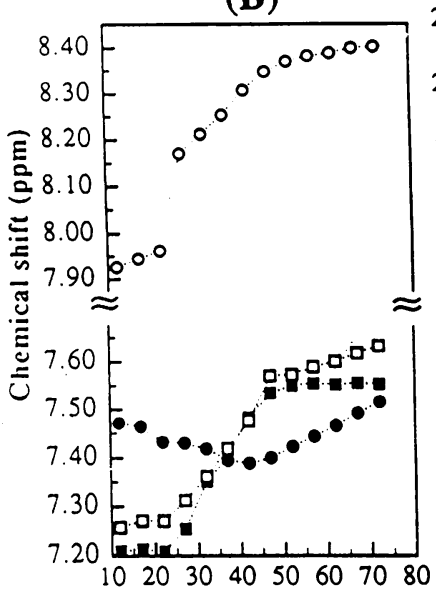

(C)

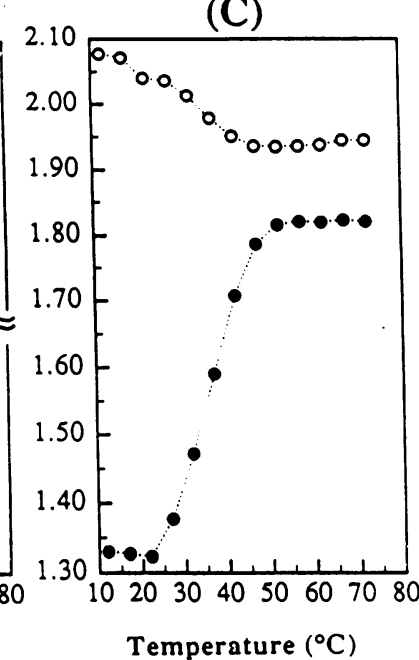

(D)

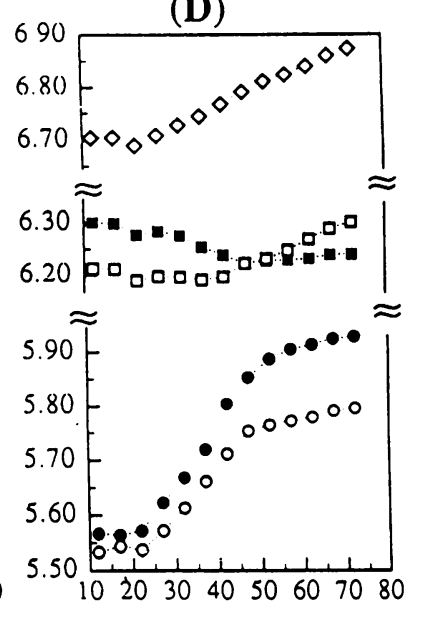

Figure 1. (A) Comparison of the first derivative $\left(\Delta \mathrm{A}_{260} / \Delta T\right.$ where $\mathrm{A}$ indicates $\mathrm{UV}$ absorption at $\left.260 \mathrm{~nm}\right)$ of the UV melting curve (25 $\left.\mu \mathrm{M}\right)$ of (1) the unmodified hybrid DNA - RNA duplex, r(GAUUGAA):d(TCAATC) $\left(T_{\mathrm{m}}=5^{\circ} \mathrm{C}\right)$ with (2) $3^{\prime}$-Pzn-tethered DNA-RNA hybrid, r(5'GAUUGAA3'):d(5'TCAATC3'-Pzn) $\left(T_{\mathrm{m}}\right.$ $=18^{\circ} \mathrm{C}$ ). Under the conditions of the measurement of the melting point, the $3^{\prime}$-Pzn-tethered DNA - RNA hybrid [i.e. duplex $\left.(2)\right]$ is found to be stable by $13^{\circ} \mathrm{C}$ compared to the natural duplex (1). (B-D) Chemical shifts versus the temperature profiles of some protons of hybrid DNA-RNA duplex, r(5'GAUUGAA3'): d(5'TCAATC3'-Pzn). The base proton resonances: $(B) \mathrm{H}^{\prime} \mathrm{T}^{12}(\square), \mathrm{H}^{12} \mathrm{C}^{13}(\bullet), \mathrm{H}^{\prime} \mathrm{A}^{7}(\bigcirc)$ and $\mathrm{H} 3 \mathrm{Pzn}(\square),(\mathrm{C})$ the methyl groups of $\mathrm{T}^{12}(\bullet)$ and $\mathrm{T}^{8}\left(\mathrm{O}^{\prime}\right)$, and (D) the $\mathrm{H}^{\prime}$ of $\mathrm{T}^{8}(\square)$ and $\mathrm{A}^{11}(\square)$ and $\mathrm{H} 5$ of $\mathrm{U}^{4}(\bullet)$ and $\mathrm{C}^{13}(\mathrm{O})$ and $\mathrm{H} 1 \mathrm{Pzn}(\diamond)$. The transition temperature is at $\sim 40^{\circ} \mathrm{C}$.

\section{RESULTS AND DISCUSSION}

\section{Assignment of the non-exchangeable protons}

The assignment of the non-exchangeable protons (Table 1) in the duplex was made in the usual sequential manner from a NOESY spectrum. The four strong $\mathrm{H} 5-\mathrm{H} 6$ crosspeaks from the uridines and cytidines and the two methyl resonances from the thymidines were easily identified from both NOESY and DQF-COSY spectra. These peaks then served as the reference points for the sequential assignments. Each $\mathrm{H} 6 / \mathrm{H} 8$ base proton showed a crosspeak with both its own $\left(\mathrm{H6} / \mathrm{H}_{(\mathrm{i})} \hookrightarrow \mathrm{H}^{\prime}{ }_{(\mathrm{i})}\right)$ and its $5^{\prime}$-linked residue $\mathrm{H}^{\prime}{ }^{\prime}\left(\mathrm{H} 6 / \mathrm{H}_{(\mathrm{i})} \hookrightarrow \mathrm{H}^{\prime}{ }_{(\mathrm{i}-1)}\right)$. This allowed us in a straightforward way to connect all residues in both the RNA $\left(G^{1} \rightarrow A^{7}\right)$ and the DNA strand $\left(T^{8} \rightarrow C^{13}\right)$ (Fig. 2A). In the RNA strand the overlapping peaks of $\mathrm{H} \mathrm{G}^{1}(8.13 \mathrm{ppm}) \hookrightarrow \mathrm{H}^{\prime} \mathrm{G}^{1}$
(5.71 ppm) and $\mathrm{H} 8 \mathrm{~A}^{2}(8.16 \mathrm{ppm}) \longrightarrow \mathrm{H}^{\prime} \mathrm{G}^{1}$ (5.71 ppm) (Fig. 2A) were resolved on the other side of the diagonal and could thus be assigned unequivocally. The crosspeaks of $\mathrm{H}^{8} \mathrm{G}^{5}(7.65$ $\mathrm{ppm}) \longrightarrow \mathrm{H} 1^{\prime} \mathrm{U}^{4}(5.69 \mathrm{ppm})$ and $\mathrm{H}^{4} \mathrm{G}^{5}(7.65 \mathrm{ppm}) \longrightarrow \mathrm{H} 1^{\prime} \mathrm{G}^{5}$ (5.69 ppm) are overlapped (Fig. 2A) in $12^{\circ} \mathrm{C}$ NOESYspectra, nevertheless they could be unambiguously assigned at $0^{\circ} \mathrm{C}$. The assignment of the DNA strand could however be done in a straightforward manner starting either at the $5^{\prime}$ end $\left[\mathrm{H}^{\mathrm{T}} \mathrm{T}^{8}(8.07\right.$ $\left.\mathrm{ppm}) \rightarrow \mathrm{H}^{\prime} \mathrm{T}^{8}(6.31 \mathrm{ppm})\right]$ or at the $3^{\prime}$ end $\left[\mathrm{H}^{6} \mathrm{C}^{13}(7.49\right.$ $\mathrm{ppm}) \longrightarrow \mathrm{H}^{\prime} \mathrm{C}^{13}$ (5.99 ppm)] (Fig. 2A). This assignment was further corroborated by the $\left.\mathrm{H} 6 / \mathrm{H}_{(\mathrm{i})} \rightarrow \mathrm{H} 2^{\prime}{ }_{(\mathrm{i}, \mathrm{i}}-1\right)$ and $\mathrm{H} 6 / \mathrm{H}_{(\mathrm{i})} \longrightarrow \mathrm{H}^{\prime}{ }_{(\mathrm{i}, \mathrm{i}-1)}$ pathways of the RNA strand (Fig. 2B, C) and by the $\mathrm{H} 6 / \mathrm{H8}_{(\mathrm{i})} \longleftrightarrow \mathrm{H} 2^{\prime} / 2^{\prime}{ }_{(\mathrm{i}, \mathrm{i}}$ - 1) pathway of the DNA strand (Fig. 2D). Fig. 2 also shows severe overlaps in the aromatic to $\mathrm{H} 2^{\prime} / \mathrm{H}^{\prime}$ area of the RNA strand, which becomes 
Table 1. ${ }^{1} \mathrm{H}$ chemical shifts of hybrid DNA-RNA duplex r(5'GAUUGAA3'):d(5'TCAATC $3^{\prime}-$ Pzn $)$ at $12^{\circ} \mathrm{C}$

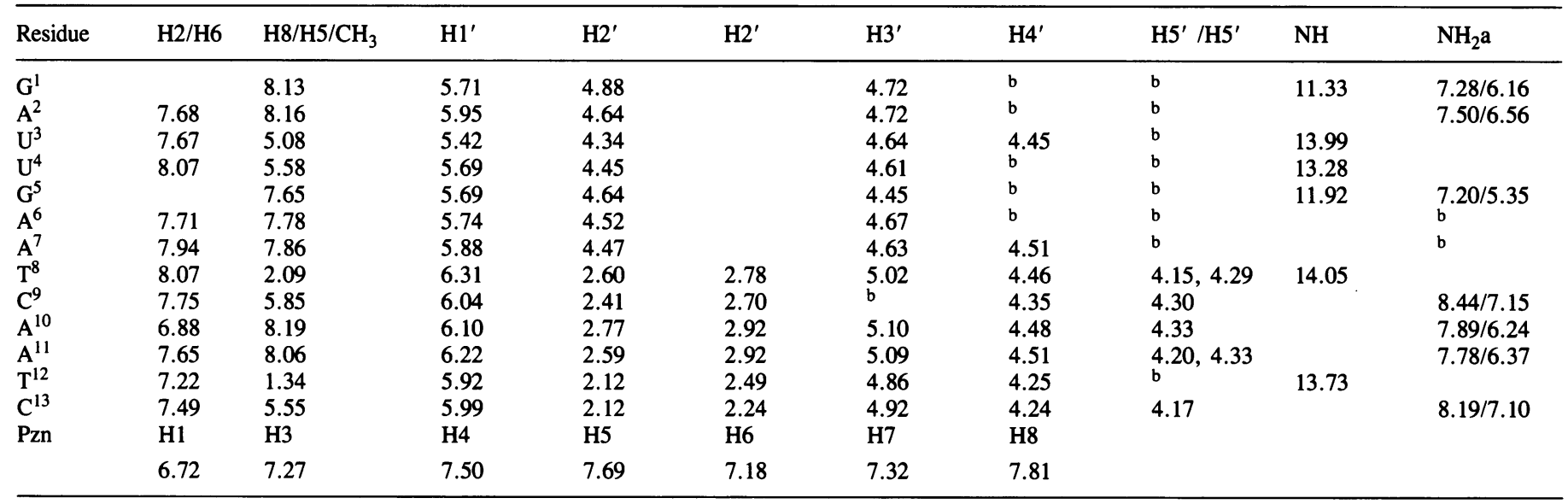

${ }^{a}$ for $\mathrm{NH}_{2}$ the first chemical shift is for the hydrogen bonded proton and the second is for the non-hydrogen bonded proton.

${ }^{b}$ Could not be obtained due to overlap of signals.

Table 2. Coupling constants obtained in $\mathrm{Hz}$ after simulation of the observable experimental crosspeaks of the DQF-COSY spectra and calculated best fit sugar pucker of the hybrid DNA-RNA duplex r $\left(5^{\prime}\right.$ GAUUGAA $\left.^{3^{\prime}}\right)$ : d $\left(5^{\prime}\right.$ TCAATC $^{3^{\prime}}-$ Pzn $)$ at $12^{\circ} \mathrm{C}$

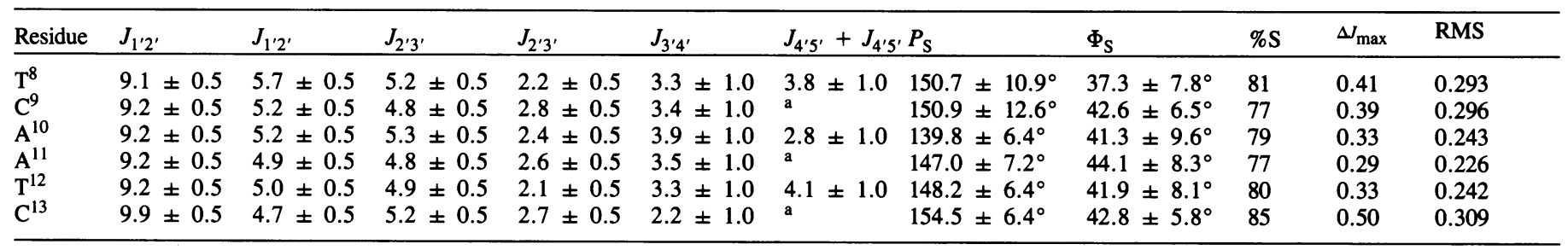

${ }^{a}$ Could not be observed.

The program PSEUROT was run with $P_{\mathrm{N}}$ and $\Phi_{\mathrm{N}}$ fixed at different values $\left(9^{\circ}<P_{\mathrm{N}}>-9^{\circ}, 32^{\circ} \Phi_{\mathrm{N}}>42^{\circ}\right)$ and they had no effect on the final result while $P_{\mathrm{S}}, \Phi_{\mathrm{S}}$ and $\% \mathrm{~S}$ were iterated by the program. All permutations using the maximum and minimum possible coupling constants were also assessed and the errors presented in $P_{S}$ and $\Phi_{S}$ are the standard deviations of those runs.

$\Delta J_{\max }$ is the largest difference between the coupling constants calculated by PSEUROT and the experimental coupling constants.

still more intricate with a larger RNA strand making it a challenging task (11) to extract any useful information (see the legend to Fig. 2 for full assignments).

\section{Assignment of the exchangeable protons and H2A protons}

The chemical shifts of the exchangeable protons are given in Table 1. The H2A protons were assigned from the imino protons following the $\mathrm{d} / \mathrm{rA}\left(\mathrm{H} 2_{(\mathrm{i})}\right) \longrightarrow \mathrm{dT} / \mathrm{rU}\left(\mathrm{imino}_{(\mathrm{i}}+1\right.$ or j $)$ ) pathway (data not shown). The $\mathrm{N}^{1} \mathrm{HG}^{1}(11.33 \mathrm{ppm})$ imino proton has a crosspeak with $\mathrm{H}_{2} \mathrm{~A}^{2}(7.68 \mathrm{ppm})$ which in turn has a crosspeak with $\mathrm{N}^{3} \mathrm{HT}^{12}$ (13.73 ppm). Similarily the $\mathrm{N}^{2} \mathrm{HU}^{3}$ (13.99 $\mathrm{ppm}) \longrightarrow \mathrm{H}^{2} \mathrm{~A}^{11}(7.65 \mathrm{ppm}) \rightarrow \mathrm{N}^{11} \mathrm{HU}^{4}(13.28 \mathrm{ppm}), \mathrm{N} 3 \mathrm{HU}^{4}$ $(13.28 \mathrm{ppm}) \rightarrow \mathrm{H}^{2} \mathrm{~A}^{10}(6.88 \mathrm{ppm}) \rightarrow \mathrm{N}^{1} \mathrm{HG}^{5}(11.92 \mathrm{ppm})$ and $\mathrm{N} 1 \mathrm{HG}^{5}(11.92 \mathrm{ppm}) \longrightarrow \mathrm{H} 2 \mathrm{~A}^{6}(7.71 \mathrm{ppm}) \hookrightarrow \mathrm{N}^{3} \mathrm{HT}^{8}(14.05$ ppm) connections could be established and the $\mathrm{H} 2$ protons assigned. The remaining $\mathrm{H} 2$ resonance (detected in the inversion recovery experiment) was assigned as $\mathrm{H}_{2} \mathrm{~A}^{7}$.

\section{Assignment of the $\mathrm{N}$-(2-hydroxyethyl)phenazinium protons}

The assignment of all coupled protons $\mathrm{H} 1, \mathrm{H} 3, \mathrm{H} 4, \mathrm{H} 5, \mathrm{H} 6$, $\mathrm{H} 7, \mathrm{H8},{ }^{13} \mathrm{CH}_{2}$ - and ${ }^{14} \mathrm{CH}_{2}$ - protons of the Pzn residue were made from both NOESY and DQF-COSY spectra $(6 \mathrm{~b}, \mathrm{e})$. In NOESY additional crosspeaks could be found between $\mathrm{H} 1$ and $\mathrm{H} 8$, between $\mathrm{H} 1$ and ${ }^{-13} \mathrm{CH}_{2}$ - and ${ }^{-14} \mathrm{CH}_{2}$ - and between $\mathrm{H} 3$ and
${ }^{-14} \mathrm{CH}_{2}$ - of the linker. The protons of the hydroxyethyl group could not be assigned.

\section{Stereochemical orientation of the phenazinium ring}

There are several crosspeaks in the NOESY spectra that have enabled us to determine the stereochemical orientation of the Pzn ring. Both the $\mathrm{H} 7$ and $\mathrm{H} 8$ protons of Pzn have crosspeaks to the $\mathrm{H}^{\prime}$ proton of $\mathrm{G}^{1}$. The H3Pzn proton has crosspeaks to the $\mathrm{H} 2^{\prime}$, $\mathrm{H} 2^{\prime}$ and $\mathrm{H} 5$ protons of ${ }^{13} \mathrm{C}$ and with the slowly exchangeable imino proton of the linker (visible in the NOESY spectra recorded in $90 \% \mathrm{H}_{2} \mathrm{O}$ ). This allowed us to stereochemically orientate the Pzn ring with respect to the linker and also unambigously set the linker to the cis orientation with respect to $\mathrm{H} 1$ and ${ }^{13} \mathrm{CH}_{2}-$ or ${ }^{2} \mathrm{CNH}$ and $\mathrm{H} 3\left[\phi\left({ }^{1} \mathrm{C}^{-2} \mathrm{C}_{-}{ }^{2} \mathrm{CNH}-{ }^{13} \mathrm{C}\right)=0^{\circ}\right](6 \mathrm{~b})$ which is consistent with our earlier observations for the DNA-tethered Pzn duplex (6b).

\section{Conformation of the sugar rings}

The conformation of the sugar rings of the DNA strand could be determined from the $J_{\mathrm{H}^{\prime}-\mathrm{H}^{\prime}}, J_{\mathrm{H}^{\prime}-\mathrm{H}^{\prime}}, J_{\mathrm{H}^{\prime}-\mathrm{H}^{\prime}}, J_{\mathrm{H}^{\prime}-\mathrm{H} 3^{\prime}}$ and $J_{\mathrm{H}^{\prime}-\mathrm{H}^{\prime}}$ coupling constants obtained from DQF-COSY. These coupling constants were then further refined by simulation with the SMART program (9a) and are presented in Table 2 . The phase angles $(P)$ and the puckering amplitudes $(\Phi)$ of each sugar 
(A)
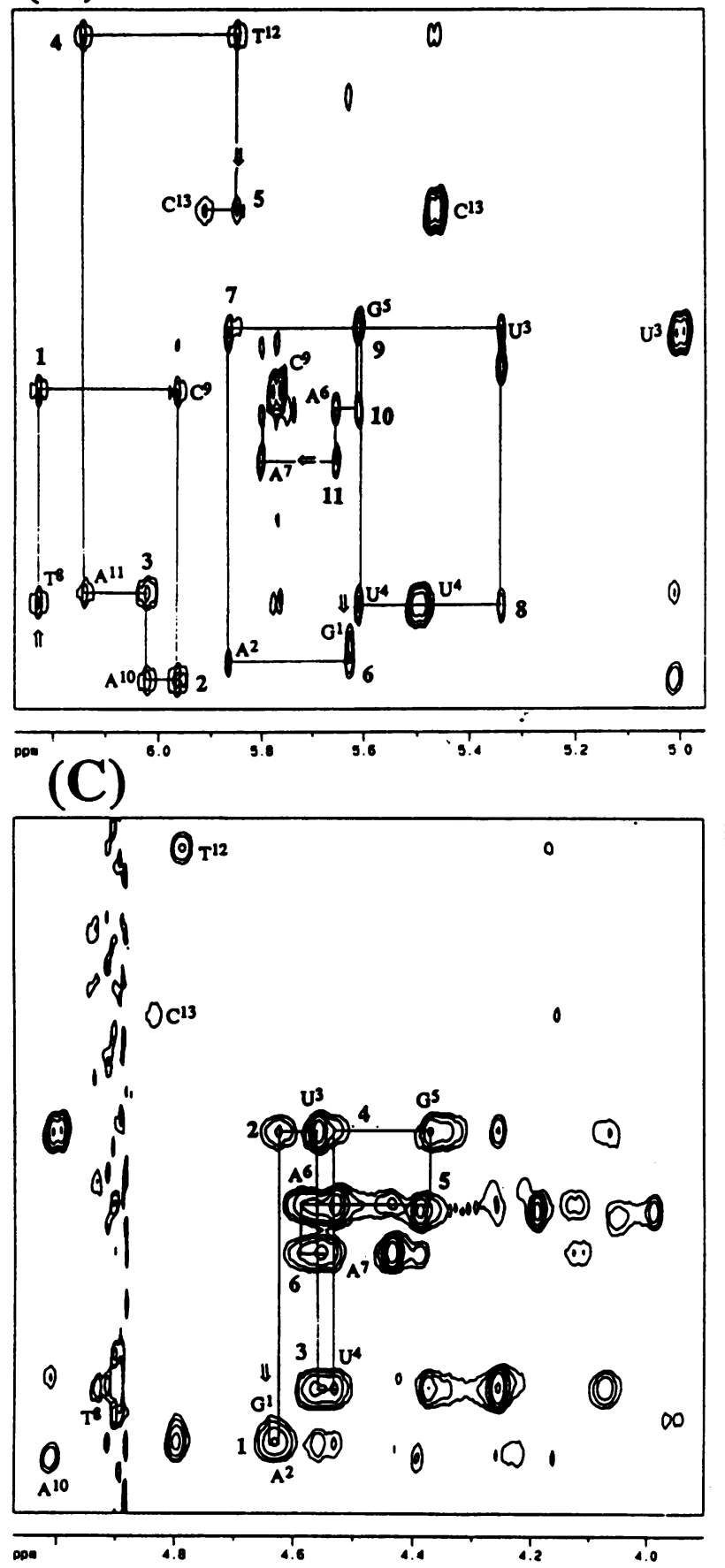

(B)

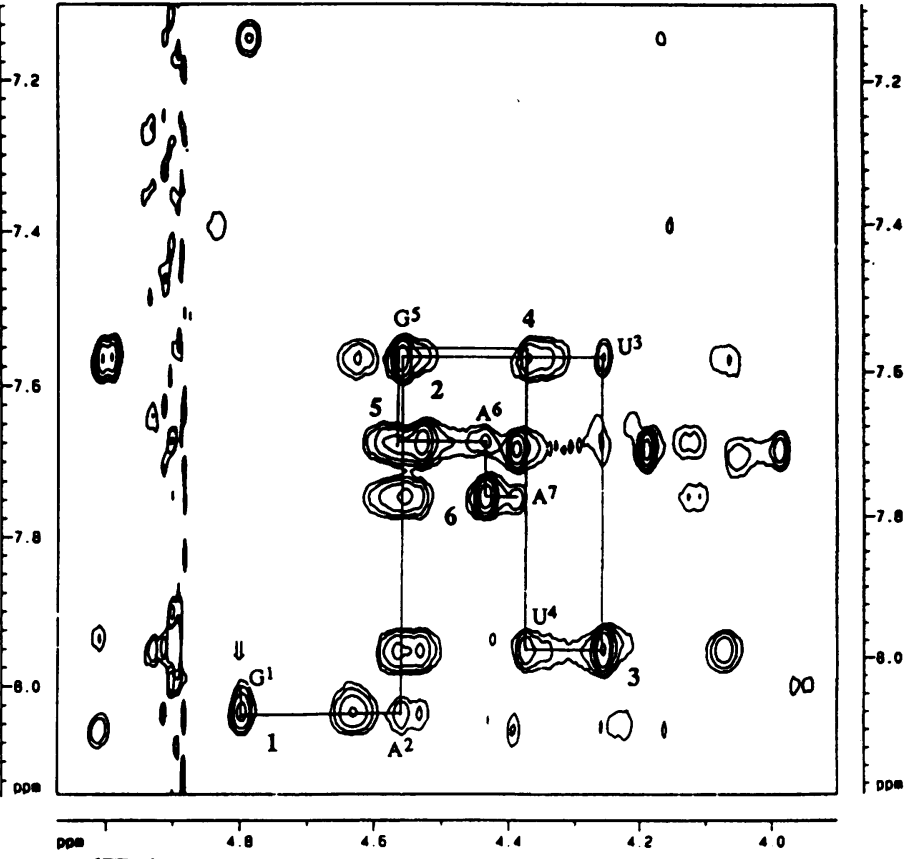

(D)

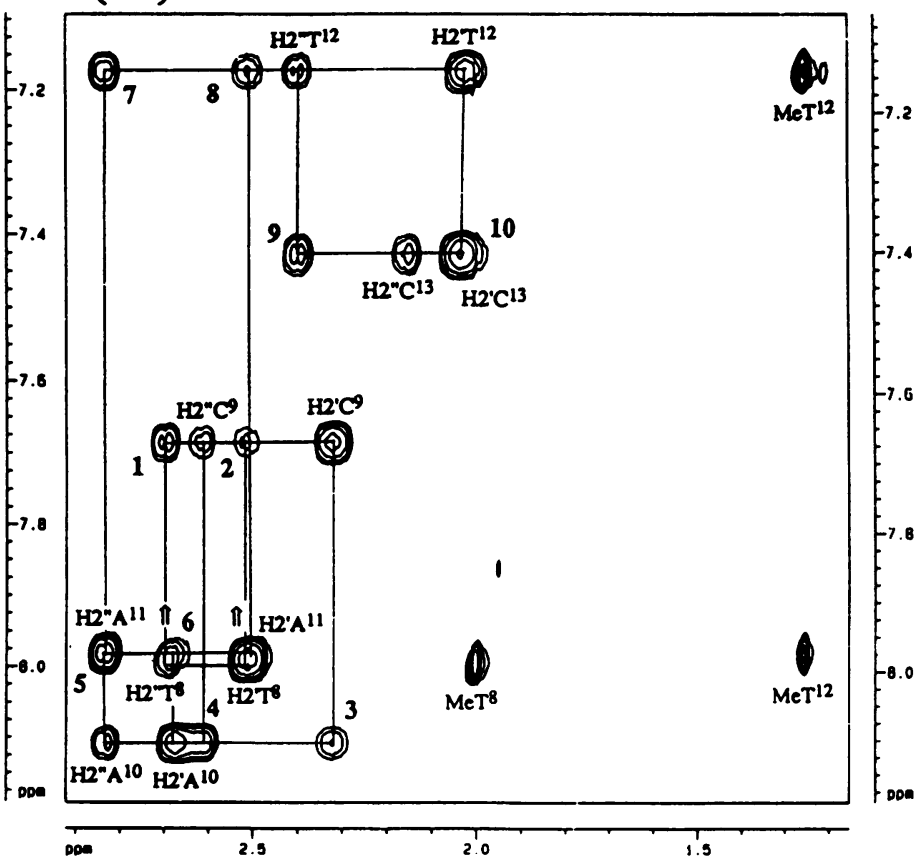

Figure 2. Expanded plots of the NOESY spectra $(150 \mathrm{~ms})$ of the hybrid $r\left(5^{\prime}\right.$ GAUUGAA3'): $d\left(5^{\prime}\right.$ TCAATC $\left.3^{\prime}-\mathrm{Pzn}\right)$ in $\mathrm{D}_{2} \mathrm{O}$ at $12^{\circ} \mathrm{C}$. Crosspeaks in $(\mathrm{A})$ show the sequential aromatic to $\mathrm{H}^{\prime}$ connectivities for both the RNA and the DNA strand. The assignment of the RNA strand starts with the 5'-end, i.e. from H8G ${ }^{1}(8.13$ $\mathrm{ppm})-\mathrm{H}^{\prime} \mathrm{G}^{1}(5.71 \mathrm{ppm})$ crosspeak. Similarly, we also start with the $5^{\prime}$-end for the DNA strand, i.e. $\mathrm{H}^{2} \mathrm{~T}^{8}(8.07 \mathrm{ppm})-\mathrm{H}^{\prime} \mathrm{T}^{8}(6.31 \mathrm{ppm}) \mathrm{crosspeak}$. Both are marked with arrows showing the direction of the assignment. The assignment of the inter-residual crosspeaks are as follows (marked by arabic numbers): (1)

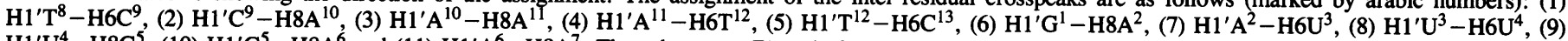
$\mathrm{H}^{\prime} \mathrm{U}^{4}-\mathrm{H}^{2} \mathrm{G}^{5}$, (10) $\mathrm{H}^{\prime} \mathrm{G}^{5}-\mathrm{H}_{8 \mathrm{~A}^{6}}$ and (11) $\mathrm{H}^{\prime} \mathrm{A}^{6}-\mathrm{H} 8 \mathrm{~A}^{7}$. The subspectra (B) and (C) show the same part of the spectrum. In (B), the sequential $\mathrm{H} 6 / \mathrm{H} 8$ to the $\mathrm{H}^{\prime}$ crosspeaks of the RNA strand are traced and starts with the $5^{\prime}$-end: $\mathrm{H}^{2} \mathrm{G}^{1}(8.13 \mathrm{ppm})-\mathrm{H}^{\prime} \mathrm{G}^{1}(4.88 \mathrm{ppm})$ crosspeak. The assignment of the inter-residual crosspeaks

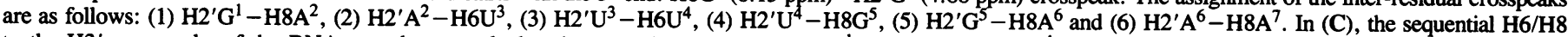
to the $\mathrm{H}^{\prime}$ ' crosspeaks of the RNA strand are marked and starts with the $5^{\prime}$-end: $\mathrm{H}^{\prime} \mathrm{G}^{1}(8.13 \mathrm{ppm})-\mathrm{H}^{\prime} \mathrm{G}^{1}(4.72 \mathrm{ppm})$ crosspeak. The assignment of the interresidual $\mathrm{H} 6 / \mathrm{H} 8$ to the $\mathrm{H}^{\prime}$ crosspeaks are as follows: (1) $\mathrm{H}^{\prime} \mathrm{G}^{1}-\mathrm{H}_{8 \mathrm{~A}^{2}}$, (2) $\mathrm{H}^{\prime} \mathrm{A}^{2}-\mathrm{H}^{\prime} \mathrm{U}^{3}$, (3) $\mathrm{H}^{\prime} \mathrm{U}^{3}-\mathrm{H}^{\prime} \mathrm{U}^{4}$, (4) $\mathrm{H}^{\prime} \mathrm{U}^{4}-\mathrm{H}^{\prime} \mathrm{G}^{5}$, (5) $\mathrm{H}^{\prime} \mathrm{G}^{5}-\mathrm{H}^{\prime} \mathrm{A}^{6}$ and (6) $\mathrm{H}^{\prime} \mathrm{A}^{6}-\mathrm{H}_{8} \mathrm{~A}^{7}$. In (D), the sequential $\mathrm{H6} / \mathrm{H} 8$ to the $\mathrm{H} 2^{\prime} / \mathrm{H}^{\prime}$ crosspeaks of the DNA strand are traced and starts with the $5^{\prime}-\mathrm{end}^{\prime} \mathrm{H}^{\prime} \mathrm{T}^{8}(8.07 \mathrm{ppm})-\mathrm{H}^{\prime} / \mathrm{H}^{\prime} \mathrm{T}^{8}$ $(2.60,2.78 \mathrm{ppm})$ crosspeak. The assignment of the inter-residual crosspeaks are as follows: $(1,2) \mathrm{H} 2^{\prime} / 2^{\prime} \mathrm{T}^{8}-\mathrm{H} 6 \mathrm{C}^{9},(3,4) \mathrm{H}^{\prime} / 2^{\prime} \mathrm{C}^{9}-\mathrm{H}^{\prime} \mathrm{A}^{10},(5,6) \mathrm{H}^{\prime} / 2^{\prime} \mathrm{A}^{10}-\mathrm{H}_{8} \mathrm{~A}^{11}$, $(7,8) \mathrm{H}^{\prime} / 2^{\prime} \mathrm{A}^{11}-\mathrm{H}_{6} \mathrm{~T}^{12},(9,10) \mathrm{H} 2^{\prime} / 2^{\prime} \mathrm{T}^{12}-\mathrm{H}_{6} \mathrm{C}^{13}$. Note that only the intra-residue $\mathrm{H} 6 / \mathrm{H} 8$ to $\mathrm{H} 1^{\prime} / \mathrm{H} 2^{\prime} / \mathrm{H} 2^{\prime} / \mathrm{H}^{\prime}$ crosspeaks are labeled in the figure. 
Table 3. Torsional constraints calculated from pseudorotational parameters $(\mathrm{P}, \Phi)$ and ${ }^{3} J_{\mathrm{HH}}$ (Table 2) and distance constraints for $\epsilon$ used in $\mathrm{MD}$ calculations

\begin{tabular}{|c|c|c|c|c|c|}
\hline Residue & $\mathrm{C} 2^{\prime}-\mathrm{C} 3^{\prime}$ & $C 3^{\prime}-C 4^{\prime}$ & $\epsilon^{\mathrm{a}}(\AA)$ & $\beta$ & $\gamma$ \\
\hline $\mathrm{G}^{1}$ & $35.5 \pm 5.5^{\circ}$ & $-30.5 \pm 6.5^{\circ}$ & $2.45-3.07$ & & $60 \pm 40^{\circ}$ \\
\hline$A^{2}$ & $35.5 \pm 5.5^{\circ}$ & $-30.5 \pm 6.5^{\circ}$ & $2.45-3.07$ & $180 \pm 75^{\circ}$ & $60 \pm 40^{\circ}$ \\
\hline $\mathrm{U}^{3}$ & $35.5 \pm 5.5^{\circ}$ & $-30.5 \pm 6.5^{\circ}$ & $2.45-3.07$ & & \\
\hline $\mathrm{U}^{4}$ & $35.5 \pm 5.5^{\circ}$ & $-30.5 \pm 6.5^{\circ}$ & $2.45-3.07$ & b & b \\
\hline$G^{5}$ & $35.5 \pm 5.5^{\circ}$ & $-30.5 \pm 6.5^{\circ}$ & $2.45-3.07$ & b & b \\
\hline$A^{6}$ & $35.5 \pm 5.5^{\circ}$ & $-30.5 \pm 6.5^{\circ}$ & $2.45-3.07$ & $\mathrm{~b}$ & b \\
\hline$A^{7}$ & $35.5 \pm 5.5^{\circ}$ & $-30.5 \pm 6.5^{\circ}$ & & $180 \pm 75^{\circ}$ & $60 \pm 40^{\circ}$ \\
\hline $\mathrm{T}^{8}$ & $-6.2 \pm 32.1^{\circ}$ & $17.8 \pm 7.3^{\circ}$ & $2.80-3.25$ & $180 \pm 75^{\circ}$ & $60 \pm 40^{\circ}$ \\
\hline$A^{10}$ & $-31.4 \pm 6.5^{\circ}$ & $9.8 \pm 4.2^{\circ}$ & $2.80-3.25$ & $180 \pm 75^{\circ}$ & $60 \pm 10^{\circ}$ \\
\hline $\mathrm{A}^{11}$ & $-36.8 \pm 6.2^{\circ}$ & $15.7 \pm 4.9^{\circ}$ & $2.80-3.25$ & $180 \pm 75^{\circ}$ & $60 \pm 40^{\circ}$ \\
\hline $\mathrm{T}^{12}$ & $-35.5 \pm 5.9^{\circ}$ & $15.8 \pm 4.4^{\circ}$ & $2.80-3.25$ & $180 \pm 75^{\circ}$ & $60 \pm 10^{\circ}$ \\
\hline $\mathrm{C}^{13}$ & $-38.6 \pm 4.4^{\circ}$ & $20.4 \pm 3.3^{\circ}$ & $2.80-3.25$ & $180 \pm 75^{\circ}$ & $60 \pm 40^{\circ}$ \\
\hline
\end{tabular}

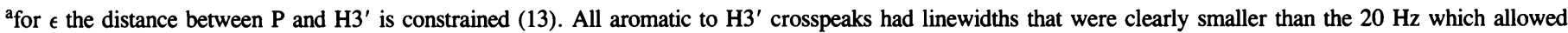

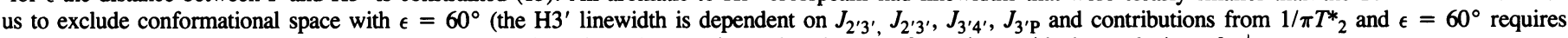
the $J_{3^{\prime} \mathrm{P}}$ to be larger than $20 \mathrm{~Hz}$ ). The distances for $\epsilon$ include both $\mathrm{B}_{\mathrm{I}}$ and $\mathrm{B}_{\mathrm{II}}$ phosphate conformations with the exclusion of $\epsilon^{+}$rotamer.

${ }^{b}$ Could not be calculated due to the overlap of the crosspeaks of interest.

$C 2^{\prime}-C 3^{\prime}: \nu_{2}=\Phi * \cos (P)$ and $C 3^{\prime}-C 4^{\prime}: \nu_{3}=\Phi * \cos (P+4 \pi / 5)$. The errors in $C 2^{\prime}-C 3^{\prime}$ and $C 3^{\prime}-C 4^{\prime}$ are calculated using the maximum errors from Table 2 .

Table 4. Atomic RMSD (̊) comparison of starting and final structures ${ }^{\mathrm{a}}$

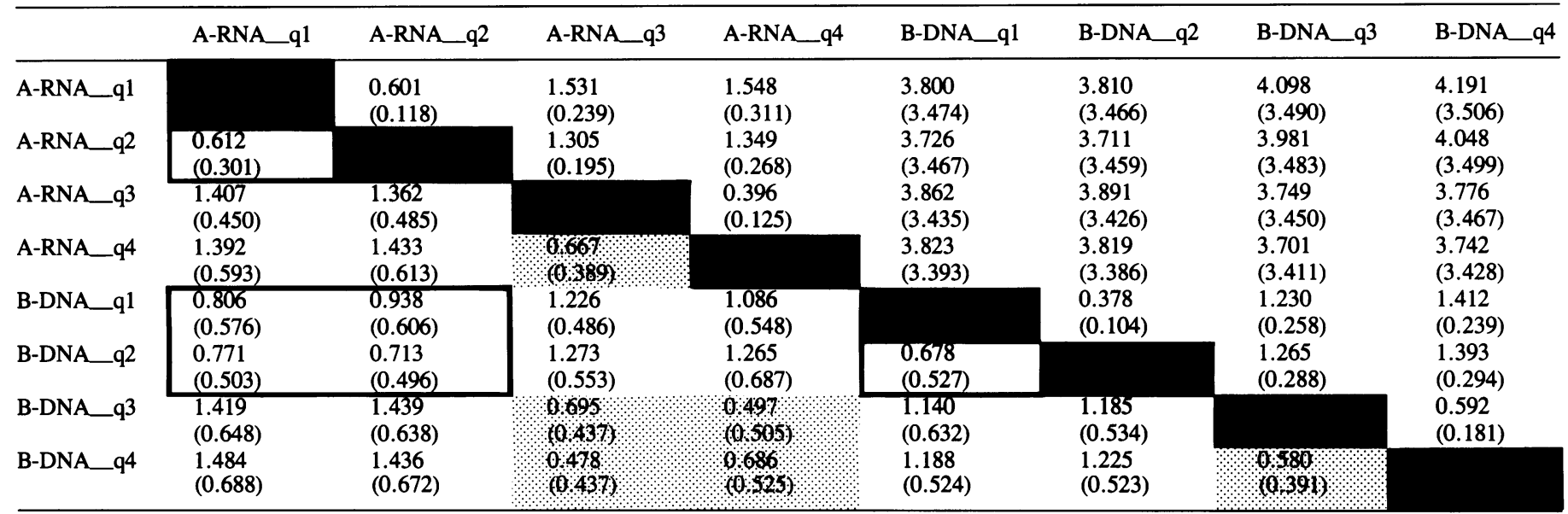

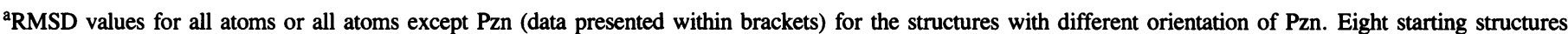
have been compared to each other above the diagonal and those after MD/MARDIGRAS refinement below the diagonal. The eight starting structures represent two families of A- and B-type models. Each of this family has 4 structures $(q 1-q 4)$ encompassing four different stereochemical orientations of the Pzn residue: The Pzn has been stacked according to the NOESY data with the neighbouring base pair $\mathrm{G}^{1}-\mathrm{C}^{13}$ while its $N$-hydroxyethyl group is orientated either to the minor groove in q1 and q2 or to the major groove in q3 and q4. In q1 and q3, the terminal hydroxymethylene moiety of $N$-hydroxyethyl is facing out from the duplex, whereas in $\mathrm{q} 2$ and $\mathrm{q} 4$ it is faces into the duplex. The comparison within the $\mathrm{q} 1$ and $\mathrm{q} 2$ and the $\mathrm{q} 3$ and $\mathrm{q} 4$ groups of structures are shown by boxes and shading, respectively.

moiety were obtained from the program PSEUROT $(9 b)$ using the three-bond coupling constant information, and the endocyclic torsional angles were derived (Table 3). All sugar residues of the DNA strand were found to be in a South-type conformation $\left(140^{\circ}<P_{\mathrm{S}}<155^{\circ}\right.$ and $\left.37^{\circ} \Phi_{\mathrm{S}}<44^{\circ}\right)$. No $J_{\mathrm{H}^{\prime}-\mathrm{H} 2^{\prime}}$ crosspeaks could be observed for the RNA strand in the DQFCOSY spectra, which is probably due to both smaller coupling constants $(<1 \mathrm{~Hz})$ and the line-broadening. The small $J_{\mathrm{H}^{\prime}-\mathrm{H} 2^{\prime}}$ coupling constant implies that all the sugar residues of the RNA strand adopt an N-type conformation $\left(P=8 \pm 28^{\circ}\right.$ and $\Phi=$ $\left.36.5 \pm 6.5^{\circ}\right)(12 \mathrm{~b})$, and thus are accordingly constrained in our calculation.

\section{Conformation of the $\epsilon, \beta$ and $\gamma$ torsional angles}

These torsional angles were defined using the method of Kim et al. (13). The $\gamma$ torsional angles were constrained using both the sum of the $J_{\mathrm{H}^{\prime}-\mathrm{H} 5^{\prime}}$ and $J_{\mathrm{H}^{\prime}-\mathrm{H} 5^{\prime}}$ coupling constants (when available from DQF-COSY, see Table 2) and from the NOE volumes (NOESY spectra at $150 \mathrm{~ms}$ ) of the $\mathrm{H} 6 / \mathrm{H} 8 \longrightarrow \mathrm{H} 5^{\prime} / 5^{\prime}$ crosspeaks and from the NOE crosspeak linewidths of the aromatic to $\mathrm{H}^{\prime}$ ' crosspeaks (the $\mathrm{H} 4^{\prime}$ linewidth is dependent on $J_{3^{\prime} 4^{\prime}}, J_{4^{\prime} 5^{\prime}}, J_{4^{\prime} 5^{\prime}}, J_{4^{\prime} \mathrm{P}}$ and $1 / \pi *_{2}$ ). The volumes of all $\mathrm{H} 6 / \mathrm{H} 8 \rightarrow \mathrm{H}^{\prime} / 5^{\prime}$ crosspeaks are smaller than the volumes of the H6/H8 $\longrightarrow$ H1' (i.e. 3.2-3.9 $\AA$ for B-DNA). The linewidths lie in the range $11-15 \mathrm{~Hz}$ and the sum of the $J_{\mathrm{H} 4^{\prime}-\mathrm{H} 5^{\prime}}$ and $J_{\mathrm{H} 4^{\prime}-\mathrm{H} 5^{\prime}}$ coupling constants are less than $4.2 \mathrm{~Hz}$. These data are consistent with a $\gamma$ in gauche ${ }^{+}$range (13) of either $60 \pm 10^{\circ}$ (when both coupling constant, distance and linewidth information were available) or $60 \pm 40^{\circ}$ (when only distance and/or linewidth information were available). The $\epsilon$ and $\beta$ torsional angles were constrained using the linewidths of crosspeaks of $\mathrm{H} 6 / \mathrm{H} 8$ to $\mathrm{H}^{\prime}{ }^{\prime}$ or $\mathrm{H}^{\prime} / \mathrm{H} 5^{\prime}$ and $\mathrm{H} 1^{\prime}$ to $\mathrm{H} 3^{\prime}$ or $\mathrm{H} 5^{\prime} / \mathrm{H}^{\prime}$. The linewidths of $\mathrm{H} 5^{\prime} / \mathrm{H} 5^{\prime}$ protons is dependent on $J_{5^{\prime} 5^{\prime}}, J_{5^{\prime} / 5^{\prime} 4^{\prime}}, J_{5^{\prime} / 5^{\prime} \mathrm{P}}$ and $1 / \pi T_{2}$ which were found to be less than $28 \mathrm{~Hz}$. Hence, we constrained $\beta$ to $180 \pm 75^{\circ}$ in accordance with the procedure of Kim et al. (13). All linewidths of $\mathrm{H} 6 / \mathrm{H} 8$ to $\mathrm{H} 3^{\prime}$ crosspeaks were clearly 
(A)

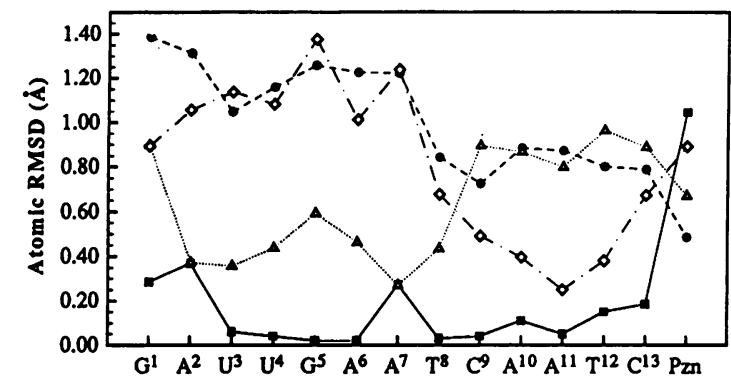

(B)

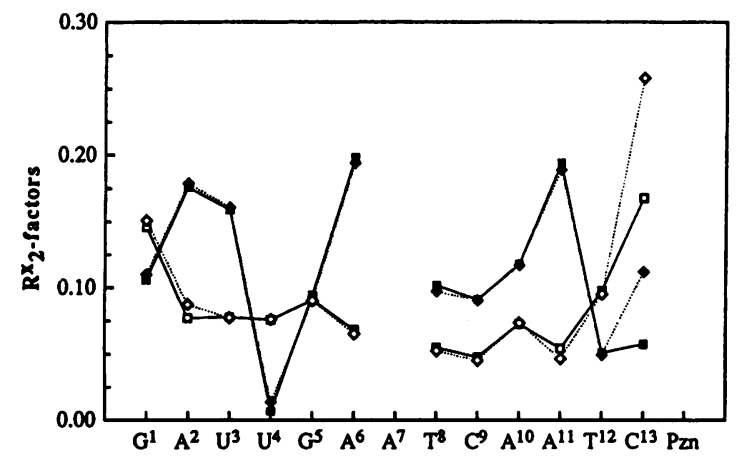

(C)

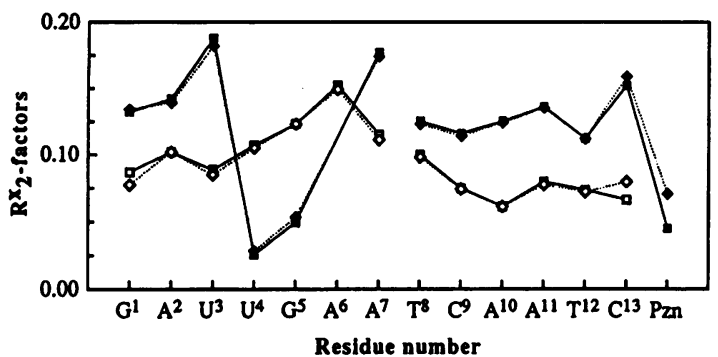

(D)<smiles></smiles>
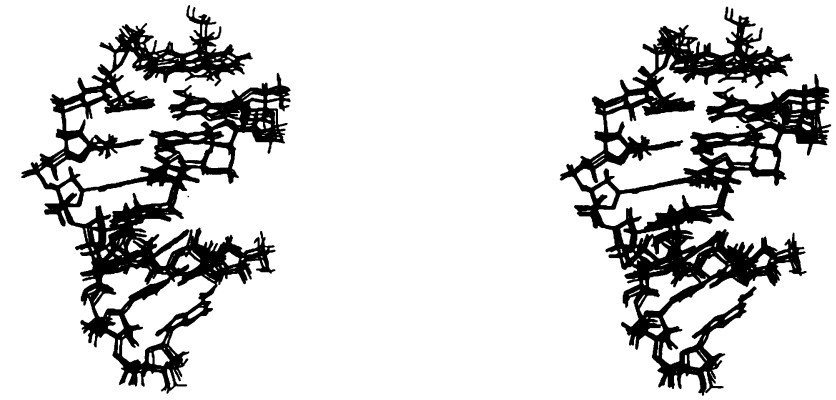

(E)

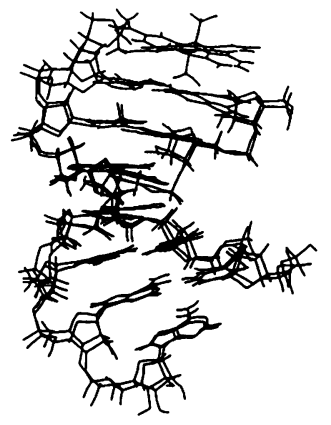

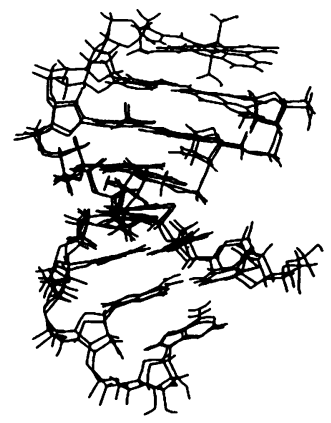

Figure 3. (A) The plot of the atomic RMSD deviations ( $\AA$ ) for each residue upon comparison of the starting structures of the A-type with the B-type of duplex $(\bullet)$, the RMSD deviations of the final structures $(q 1-q 4)$ obtained after refinement from the A- and B-type of duplex ( $\square$ ), the RMSD as a result of the comparisons of the starting and final structures of the A-type $(\Delta)$, and the starting and final structures of the B-type $(\diamond)$. (B) and (C) are the plots of 6 th root squared $R^{\times} 2$ values (10) for the inter-residual (B) and intra-residual (C) distances for each residue of the average of the final four structures in each group: (i) A-RNA_q1/q2 and B-DNA q1/q2 ( $\square$ and $\square$ ) and (ii) A-RNA_q3/q4, B-DNA_q3/q4 $(\bullet$ and $\diamond)$. The filled symbols $(\square$ and $\bullet)$ are the $R^{x} 2$ values of the average of four structures compared with the experimental NOESY spectra recorded in $\mathrm{H}_{2} \mathrm{O}$ (including exchangeable protons), whereas the empty symbols ( $\square$ and ?) are the $R^{\times} 2$ values of the average of four structures compared with the NOESY spectra recorded in $\mathrm{D}_{2} \mathrm{O}$. (D) Stereoviews of the superimposition of the eight final structures shown in Table 4 after 7 steps of MD/MARDIGRAS refinement of the hybrid DNA-RNA duplex with the atomic RMSD deviations $1.5 \AA$ with all atoms and $0.65 \AA$ excluding the Pzn residue. (E) Two different stereoviews of superimposition of the final four q1/q2 type structures after 7 steps of MD/MARDIGRAS refinement of the hybrid DNA-DNA duplex with the atomic RMSD deviations $<0.9 \AA$ (for all atoms including the Pzn residue).

smaller than $20 \mathrm{~Hz}$, which suggests that the rotamer distribution with $\epsilon=60^{\circ}$ should be excluded and accordingly the $\mathrm{H}^{\prime}-\mathrm{P}$ distance was constrained to $2.80-3.25 \AA$ and for the RNA residues $2.45-3.07 \AA$. These distances include in both cases both $B_{I}$ and $B_{I I}$ phosphate conformations.

\section{Melting properties}

Chemical shifts of nucleobase and $\mathrm{H} 1^{\prime}$ protons are sensitive to the ring current effects exerted by the adjacent nucleobases. Therefore, these chemical shifts are suitable probes to investigate the stacking interactions in oligonucleotides. The chemical shift versus temperature profiles of the DNA-RNA duplex are shown in Fig. 1B-D, and all are sigmoidal in shape. These profiles show that the duplex -monomer equilibrium shifts from the duplex structure at $<20^{\circ} \mathrm{C}$ to the monomer structures at $>50^{\circ} \mathrm{C}$. Interestingly, the profile of the H3Pzn proton also shows a sigmoidal shape, indicating that it is stacked. A perusal of these sigmoidal melting curves suggest that the $T_{\mathrm{m}}$ of the Pzn-tethered
DNA-RNA duplex and the $T_{\mathrm{m}}$ of the stacking-destacking equilibrium of the Pzn residue is $\approx 40^{\circ} \mathrm{C}$ under the NMR measurement conditions. This means that both the stacking-destacking equilibrium of the Pzn residue and the duplex-monomer equilibrium of the duplex are parts of the same process.

\section{Analysis of the structures resulting from the MD/} MADRIGRAS refinement

To find structures that are consistent with the NMR constraints, we have performed a restrained molecular dynamics (MD) calculation. In the present study, complete relaxation matrix analysis has been employed using the MARDIGRAS algorithm (10) to generate distance constraints (197 NOE constraints). The distance constraints between the aromatic to exchangeable protons were corrected (10) by using the rates of exchange of imino or amino protons with water, which also allowed us to constrain the interstrand distances. The coupling constant information from 
Nucleic Acids Research, 1994, Vol. 22, No. 255597

Table 5. Energy terms (in $\mathrm{kcal} \mathrm{mol}^{-1}$, AMBER force field) of minimized structures before and after MD and squared sixth root total indices $R^{\times} 2$ analysis using CORMA (10) for the eight starting and final structures after MD/MARDIGRAS refinement (10)

\begin{tabular}{|c|c|c|c|c|c|c|}
\hline Structure & $\begin{array}{l}\text { Potential } \\
\text { energy (no } \\
\text { constraint) }\end{array}$ & $\begin{array}{l}\text { Potential } \\
\text { energy (with } \\
\text { constraint) }^{\mathrm{b}}\end{array}$ & $\begin{array}{l}\text { Constraint } \\
\text { energy }\end{array}$ & $\begin{array}{l}\text { Potential } \\
\text { energy after } \\
\text { minimization }^{c}\end{array}$ & $\begin{array}{l}R^{\mathrm{x}} 2 \text { of the } \\
\text { starting } \\
\text { structures }\end{array}$ & $\begin{array}{l}R^{\mathrm{x}} 2 \text { of the } \\
\text { final } \\
\text { structures }\end{array}$ \\
\hline$A-R N A \_q 1$ & -122 & 269 & 149 & -115 & $0.231(0.192)$ & $0.134(0.088)$ \\
\hline$A-R N A \_q 2$ & -122 & 274 & 149 & -115 & $0.227(0.188)$ & $0.133(0.088)$ \\
\hline$A-R N A-93$ & -116 & 311 & 157 & -110 & $0.231(0.194)$ & $0.132(0.090)$ \\
\hline$A-R N A \_q 4$ & -121 & 308 & 157 & -109 & $0.230(0.195)$ & $0.135(0.092)$ \\
\hline B-DNA_q1 & -124 & 287 & 156 & -93 & $0.178(0.194)$ & $0.134(0.089)$ \\
\hline$B-D N A-q 2$ & -124 & 291 & 158 & -93 & $0.177(0.195)$ & $0.135(0.087)$ \\
\hline B-DNA-93 & -119 & 317 & 156 & -84 & $0.188(0.204)$ & $0.133(0.091)$ \\
\hline B-DNA_q4 & -114 & 304 & 153 & -83 & $0.186(0.205)$ & $0.133(0.091)$ \\
\hline
\end{tabular}

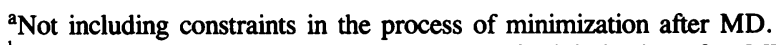

bIncluding constraint energy in the process of minimization after MD.

'Potential energy of the starting structures after minimization without constraints.

${ }^{\mathrm{d}} R^{\mathrm{x}} 2=\left[\left(\Sigma_{\mathrm{i}}\left|I_{0} 1 / 6-I_{\mathrm{c}} 1 / 6\right|\right) /\left(\Sigma_{\mathrm{i}}\left|I_{0} 1 / 6\right|\right)\right]^{2}(10)$ where $I_{0}$ and $I_{\mathrm{c}}$ are the intensities of observed non-zero and calculated NOE crosspeaks. The result of the $R^{\mathrm{x}} 2$ analysis of the starting and final structures are based on the NOE data in $\mathrm{H}_{2} \mathrm{O}$ while the data in parentheses show a similar analysis in $\mathrm{D}_{2} \mathrm{O}$ (see 10 for the procedure of analysis). Note that the $R^{\times} 2$ improves by $c$. 2 -fold in $\mathrm{D}_{2} \mathrm{O}$.

Table 6. Average backbone torsion angles, glycosidic angle $(\chi)$ and pseudorotation phase angle $(P)$ with standard deviations for 8 final structures after MD/MARDIGRAS refinement

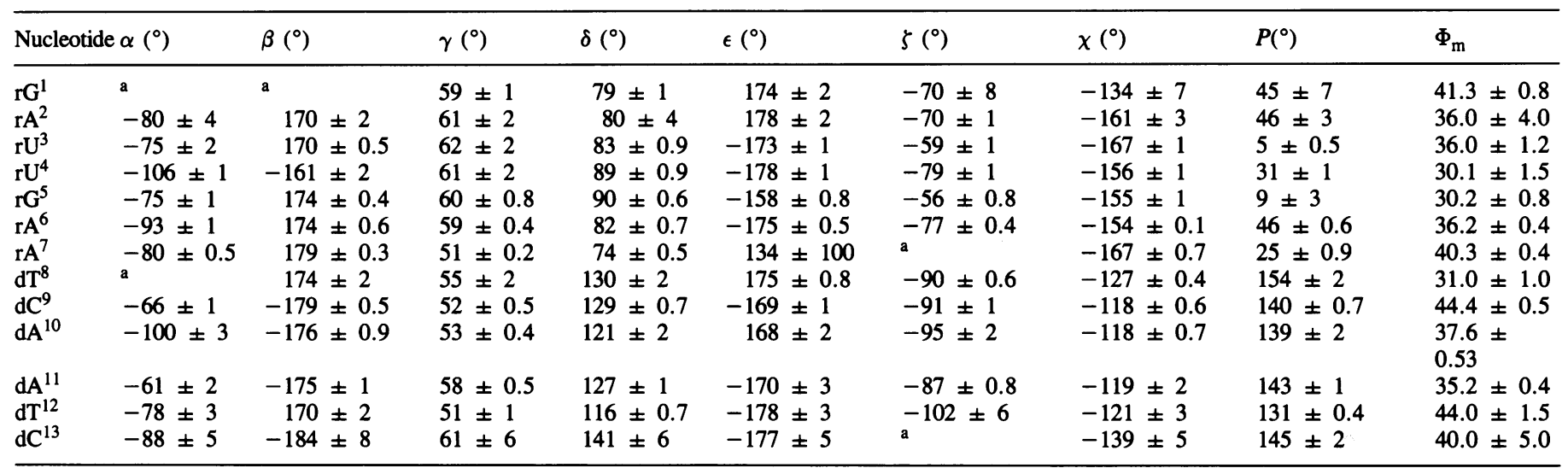

aAngle doesn't exist.

DQF-COSY experiments were used to employ the constraints for the conformation of the sugar moiety (55 dihedral angle constraints).

Analysis of both DNA and RNA strands in the hybrid DNA-RNA duplex. Eight starting structures have been used representing Aand B-type DNA or RNA (see Materials and Methods). Each of this family has 4 structures $(\mathrm{q} 1-\mathrm{q} 4)$ encompassing four different stereochemical orientations of the Pzn residue (see the legend to Table 4). The atomic RMSD values before and after the MD/MARDIGRAS refinement procedure for all eight models are also presented in Table 4. As expected, the large differences (RMSD 3.5-4.2 $\AA$ ) for the starting geometries were observed between A- and B-type families. The DNA-RNA part alone of these eight structures converged to an RMSD of $\sim 0.39-0.69$ $\AA$, whereas the RMSD including the Pzn residue varied between 0.497 and $1.433 \AA$. The analysis of RMSD values of each residue of the duplex in Fig. 3A shows the largest RMSD for all residues of the starting A- and B-type structures, which is reduced considerably in the final structures independent of whether one started from the A-RNA or B-DNA type structures. One of the important criteria to estimate the correctness of refinement procedure is the total sixth-root residual index $R^{\times} 2$, which is obtained from a direct comparison of the theoretical 2D NOE spectrum with the experimental data (10). Table 5 lists total residual indices $R^{\times 2}$ for the $150 \mathrm{~ms} 2 \mathrm{D}$ NOE data set at $0^{\circ} \mathrm{C}$ in $\mathrm{H}_{2} \mathrm{O}$ and $12^{\circ} \mathrm{C}$ in $\mathrm{D}_{2} \mathrm{O}$ calculated with the program CORMA (10) for all eight starting models and the resulting NMRconstrained MD structures after 7 steps of refinement. It may be noted that the NOE data from $\mathrm{H}_{2} \mathrm{O}$ mostly exhibit the interaction between the exchangeable protons describing both the inter- and intra-strand base-base interaction in the duplex, whereas the spectra in $\mathrm{D}_{2} \mathrm{O}$ give informations regarding the intra-strand sugar and sugar-base conformation. The $R^{\times 2}$ analysis of the final structure obtained from the NOE data sets from $\mathrm{D}_{2} \mathrm{O}$ and $\mathrm{H}_{2} \mathrm{O}$ experiments when fitted with the NOE data set in $\mathrm{D}_{2} \mathrm{O}$ or $\mathrm{H}_{2} \mathrm{O}$ shows that the $R^{\times 2}$ factor from the $\mathrm{D}_{2} \mathrm{O}$ data set gives at least two-fold improvement compared to that from $\mathrm{H}_{2} \mathrm{O}$ (Table 5).

Analysis of the stereochemical orientation of the 3'-Pzn residue. A perusal of the relative energetics in Table 5 shows that the structures q1 and q2 with the hydroxyethyl group of the Pzn residue orientated in the minor groove are energetically more preferred to $\mathrm{q} 3$ and $\mathrm{q} 4$ in which the hydroxyethyl group is orientated in the major groove. This is also consistent with the 


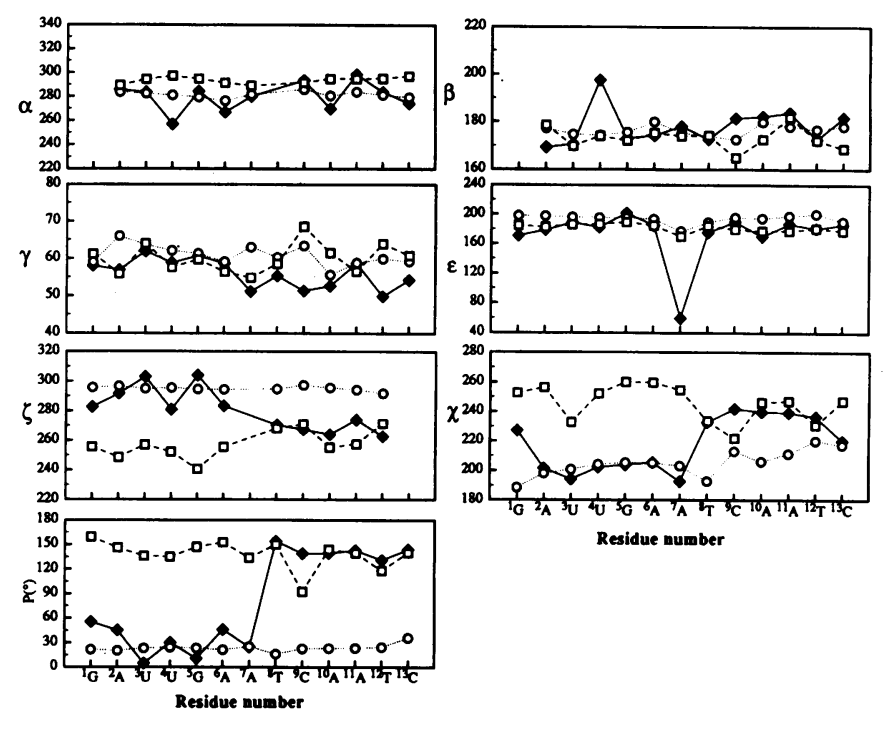

Figure 4. Plot of the torsional angles $\alpha, \beta, \gamma, \epsilon, \zeta$ and $\chi$ and the pseudorotation phase angle $(P)$ for each residue of the average structure of the final four $\mathrm{q} 1 / \mathrm{q} 2$ type structures shown in Fig. 3E obtained after 7 steps of MD/MARDIGRAS refinement $(\bullet)$ and their comparison with the starting structures $A-(O)$, and B-type ( $\square$ ) conformations.

total $R^{\times} 2$ values for $\mathrm{q} 1$ and $\mathrm{q} 2$ (Table 5). The analysis of $R^{\times 2}$ values per residue in Fig. $3 \mathrm{~B}$ and $\mathrm{C}$, where the coordinates of all $\mathrm{q} 1$ and $\mathrm{q} 2$ structures and $\mathrm{q} 3$ and $\mathrm{q} 4$ structures have been combined and averaged, shows the following. (i) The $R^{\times} 2$ values for all constituent residues of DNA and RNA (except for the Pzn residue) in all final structures in $\mathrm{D}_{2} \mathrm{O}$ or $\mathrm{H}_{2} \mathrm{O}$ are similar but the $R^{\times 2}$ values are in most cases better in $\mathrm{D}_{2} \mathrm{O}$ than in $\mathrm{H}_{2} \mathrm{O}$. (ii) The inter- and intra-residual distances between $\mathrm{Pzn}$ and the neighbouring $\mathrm{C}^{13}$ residues of $\mathrm{q} 1$ and $\mathrm{q} 2$ types of structures are always less than $\mathrm{q} 3$ and $\mathrm{q} 4$ types of structures, which are consistent with the NOE data measured under the same conditions. Note that the data on the change of chemical shifts as a function of temperature show (Fig. 1B and D) that H3Pzn and H1Pzn have the same sigmoidal melting profile $\left(T_{\mathrm{m}} \approx\right.$ $40^{\circ} \mathrm{C}$ ) as the $\mathrm{H} 2 / \mathrm{H} 6 / \mathrm{H} 8$ and the methyl protons of nucleobases, suggesting that the Pzn residue should be involved in a stacked conformation with the neighbouring $\mathrm{G}^{1}-\mathrm{C}^{13}$ base pair in the same way as other nucleobases. The inspection of eight $\mathrm{q} 1 / \mathrm{q} 2$ and $\mathrm{q} 3 / \mathrm{q} 4$ types of structures clearly shows that while the Pzn residue is indeed planar with the neighbouring base pair $\mathrm{G}^{1}-\mathrm{C}^{13}$ in the former group, it is clearly non-planar in the latter. Thus the stereoviews of the superimposition of the eight final structures described in Table 4 after MD/MARDIGRAS refinement of the hybrid DNA-RNA duplex with the atomic RMSD deviations $1.5 \AA$ with all atoms and $0.65 \AA$ excluding the Pzn residue are shown in Fig. 3D. The distinction between q1/q2 and q3/q4 types of structures was finally based on our observation of a sharp resonance in the 1D spectrum and a crosspeak with water in our NOESY spectrum for the imino proton $\left(\mathrm{NH}-\mathrm{CH}_{2} \mathrm{CH}_{2} \mathrm{O}-\right)$ of $\mathrm{Pzn}$ in $\mathrm{H}_{2} \mathrm{O}$ at $0^{\circ} \mathrm{C}$, suggesting a slow exchange process of this imino proton with water. Clearly, this is only possible if this imino proton is hydrogen bonded to some other function. In agreement with this experimental observation, we have observed that this imino proton is indeed hydrogen bonded to the nonbridging oxygen of the linker phosphate group in the final q1/q2 types of structures, lending additional support to their structural integrity. Thus all four superimposed final q1/q2 types of structures in Fig. $3 E$ (RMSD $\approx 0.7-0.9 \AA$ including all atoms of the Pzn-tethered DNA-RNA duplex) represent the NMR time-averaged conformers that can be attributed to the Pzntethered DNA-RNA hybrid duplex.

Analysis of the nucleotide conformations of the final q1/q2 type structures. A detailed comparison of the conformational preferences for the torsion angles and sugar pucker of the average from final q1/q2 type structures is given in Fig. 4 and Table 6. This shows a very small range of preference for the individual backbone angles $(\alpha, \beta, \gamma$ and $\epsilon$ ) for the $\mathrm{q} 1 / \mathrm{q} 2$ structure as found in the canonical A-RNA or B-DNA conformation. Note that $\alpha$ has not been constrained at all in our model building, the conformation space for $\epsilon^{+}$has been excluded and $\beta / \gamma$ are constrained to trans and gauche ${ }^{+}$conformations, respectively, for all DNA and some RNA residues. It means that the torsional preferences found for $\alpha, \beta, \gamma$ and $\epsilon$ merely represent the lowest energy conformation of the molecules. Nevertheless, both backbone torsion angles which define the $\mathrm{P}-\mathrm{O}$ diester bond, $\alpha$ and $\zeta$ are in the gauche $e^{-}(-\mathrm{sc})$ range. The values for $\zeta$ for the ribo strand are similar to the regular A-RNA and for the deoxyribo strand they are similar to the B-DNA type conformation. The torsion angles which define the $\mathrm{C}-\mathrm{O}-\mathrm{P}$ ester bonds $(\beta$ and $\epsilon)$ are close to the trans (+ap) value. For $\gamma$, gauche $(+\mathrm{sc})$ values are preferred. For torsion angle $\delta$ (Table 6) the values for the deoxyribo strand are in the gauche-trans range (+as), and for the ribo strand in the gauche $(+\mathrm{sc})$ range. The structural parameters of sugar pucker and the glycosidic torsion $(\chi)$ angles show a more significant discrepancy between the ribo and deoxyribo strands than for the backbone torsion angles. The $\chi$ angles are all predominantly in the anti conformation ( $-\mathrm{ac})$ range: -118 to $-127^{\circ}$ for the deoxyribonucleotides (except for the terminal $\mathrm{dC}^{13}$ residue which has $\chi \approx 139^{\circ}$ ), which are quite close to a B-type structure $\left(\chi \approx-110^{\circ}\right)$. The $\chi$ angles for the ribonucleotide residues vary from -154 to $-167^{\circ}$ in the RNA strand (Table 6) (except for the terminal $\mathrm{rG}^{1}$ residue which has $\left.\chi \approx 134^{\circ}\right)$, which are closer to A-RNA type structure $(\chi \approx$ $\left.-150^{\circ}\right)$. The pseudorotational characteristics for RNA show in part North-type sugars (close to $\mathrm{C}_{3^{\prime}}$-endo, $P=5-55^{\circ}, \Phi_{\mathrm{m}}=$ $30-45^{\circ}$ ), which are typical for A-type structures, whereas for the deoxyribonucleotides residues the phase angle varies in the South range $\left(P=131-154^{\circ}, \Phi_{\mathrm{m}}=31-45^{\circ}\right)$, which suggests a $\mathrm{C}_{1}$-exo type conformation.

\section{CONCLUSIONS}

This report constitutes a study of conformational features of a stable DNA - RNA hybrid using torsional and distance constraints (total of 252 inter- and intra-strand constraints) with a complete matrix NOE relaxation approach taking into account the exchange process with water. Several structures of DNA - RNA hybrids have been examined by NMR and X-ray crystallography. These studies suffered from two severe problems in that they had to employ a larger duplex for stability reasons, which also created inherent complexities from overlapping resonances, that, in turn, reduced the number of total constraints in the model building. These studies mainly fall into three categories: (i) the RNA and DNA strands of the chimeric duplex are similar to the corresponding A-RNA or the B-DNA $(11 \mathrm{e}, \mathrm{f})$, (ii) the RNA strand of the duplex is similar to A-RNA and the DNA strand is 
somewhat intermediate between A- and B-forms of DNA $(11 \mathrm{a}-\mathrm{d}, \mathrm{k})$, and (iii) in one crystalline duplex, the conformation of both ribose and deoxyribose sugars were in the $\mathrm{C}_{3^{\prime}}$-endo conformation, but the sugar residues in the DNA strand underwent a conformational transition to $\mathrm{C}_{2^{\prime}}$-endo in solution $(1 \mathrm{~m})$. The occurrence of all the above variations in the DNA-RNA hybrid clearly shows that the RNA sugars are invariably 3 '-endo but the DNA sugars are flexible and can indeed take up various conformations $\left(\mathrm{O}_{4^{\prime}}\right.$-endo to $\mathrm{C}_{1^{\prime}}$-exo to $\mathrm{C}_{2^{\prime}}$-endo, $72^{\circ}<P<180^{\circ}$ ).

The present investigation shows for the first time that the $3^{\prime}-\mathrm{Pzn}$ group tethered to an oligo-DNA has the unique ability to stabilize an otherwise unstable DNA-RNA hybrid duplex structure. Clearly, this finding opens enormous possibilities for the design of various heterocyclic molecule-tethered antisense DNA oligomers for use as viral RNA-directed drugs. The 3'-Pznpromoted stabilization of the DNA - RNA hybrid duplex results in detailed local conformational characteristics such as the torsion angles of the backbone and sugar moieties that are close to the features of the other normal DNA - RNA hybrids, which do not have any tethered ligand $(11 \mathrm{a}-\mathrm{m})$ (i.e. sugars of the RNA strand are 3 '-endo, but the sugars of the DNA strand are intermediate between A- and B-forms of DNA, $72^{\circ}<P<180^{\circ}$; note that the sugars of our DNA strand are $\mathrm{C}_{1^{\prime}}$-exo conformation: $131^{\circ}$ $<P<154^{\circ}$ ). This means that 3'-Pzn-tethered smaller oligoDNA could serve the same purpose as a larger oligo-DNA as a antisense inhibitor of viral mRNA. The advantage of such a DNA-tethered ligand is that they can be engineered in such a manner that it both stabilizes the DNA-RNA hybrid as well as promoting its cellular uptake. Interestingly, some initial data show that ligand-tethered oligo-DNA is more nuclease resistant (14) than the natural counterpart.

\section{ACKNOWLEDGEMENTS}

The authors thank the Swedish Board for Technical Development (NUTEK), Swedish Natural Science Research Council (NFR) and Wallenbergstiftelsen for generous financial support. We thank Professor T.James for kindly allowing us to use his MARDIGRAS (ver. 5.0).

\section{REFERENCES}

1. (a) Waring,M.J. (1981) Annu. Rev. Biochem., 50, 159-192. (b) Gilbert,D.E. and Feigon,J. (1991) Curr. Opin. Struct. Biol., 1, 439-445. (c) Wang,A.H.J. (1992) Curr. Opin. Struct. Biol., 2, 361-368. (d) Uhlmann,E. and Peuman,A. (1990) Chem. Rev., 90, 544-584. (e) Wilson,W.D., Ratmeyer,L., Zhao,M., Strekowski,L. and Boykin,D. (1993) Biochemistry, 32, 4098-4104.

2. Chu,W., Kamitori,S., Shinomiya,M., Garlson,R.G. and Takusagawa,F. (1994) J. Am. Chem. Soc., 116, 2243-2253.

3. Gryaznov,S.M. and Lloyd,D.H. (1993) Nucleic Acids Res., 21, 5909-5915.

4. (a) Letsinger,R.L. and Schott,M.E. (1981) J. Am. Chem. Soc., 103, 7394-7396. (b) Mergny,J.-L., Boutorine,A.S., Garestier,T., Belloc,F., Rougee,M., Bulychev,N.V., Koshkin, A.A., Bourson,J., Lebedev,A.V., Valeur,B., Thuong,N.T. and Hélène,C. (1994) Nucleic Acids Res., 22, 920-928. (c) Yielding,L.W., Yielding,K.L. and Donoghue,J.E. (1984) Biopolymers, 23, 83-110. (d) Lybrand,T. and Kollman,P.(1985) Biopolymers, 24, 1863-1879.

5. (a) Asseline,U., Toulme,F., Thuong.N.T., Delarue,M., MontenayGarestier,T. and Hélene,C. (1984) EMBO J., 3, 795-800. (b) Sun,J.-S., Francois,J.-C., Montenay-Garestier,T., Saison-Behmoaras,T., Roig,V., Thuong,N. T. and Hélene,C. (1989) Proc. Natl. Acad. Sci. USA, 86, 9198-9202. (c) Montenay-Garestier,T., Sun,J.S., Chomilier,J., Mergny,J.L., Takasugi,M., Asseline,U., Thuong,N.T., Rougée,M. and
Hélène,C. (1990) In Pullman,B. and Jortner,J (eds), Molecular basis of specificity in nucleic acid-drug interactions. Kluwer Academic Publisher, Juresalem, pp. 275-91. (d) Lancelot,G. and Thuong,N.T. (1986) Biochemistry, 25, 5357-5363. (e) Lancelot,G., Guesnet,J.-L., Asseline,U. and Thuong,N.T. (1988) Biochemistry, 27, 1265-1273. (f) Guesnet,J.-L., Vovelle,F., Thuong,N.T. and Lancelot,G. (1990) Biochemistry, 29, 4982-4991. (g) Lancelot,G., Guesnet,J.-L. and Vovelle,F. (1989) Biochemistry, 28, 7871-7878. (h) Thuong,N.T. and Hélène,C. (1993) Angew. Chem. (Internatl. Edn in English), 32, 666-690.

6. (a) Zarytova,V.F., Kutyavin,I.V., Sil'nikov,V.N. and Shishkin,G.V. (1986) Soviet J. Bioorg. Chem., 12, 469-477. (b) Maltseva,T.V., Sandström,A. Ivanova,E.M., Sergeyev,D.S., Zarytova,V.F. and Chattopadhyaya,J. (1993) J. Biochem. Biophys. Methods, 26, 173-236. (c) Maltseva,T.V., Agback,P and Chattopadhyay,J. (1993) Nucleic Acids Res., 21, 4246-4252. (d) Maltseva,T.V., Yamakage,S.-I., Agback,P. and Chattopadhyaya,J. (1993) Nucleic Acids Res., 21, 4288-4295. (f) Bichenkova,E.V. Zarytova,V.F., Ivanova,E.M, Lebedev,A.V, Maltseva,T.V. and Salnikov,G.E. (1992) Bioorgan. Khimi, 18, 398-412. (g) Bichenkova,E.V, Gorenstein,L.A., Vorob'ev,Yu.N., Tenne,E.Yu., Zarytova,V.F., Ivanova,E.M, Maltseva,T.V. and Lebedev,A.V. (1992) Bioorgan. Khimi, 18, $901-907$.

7. (a) Garegg,R.J., Lindh,I., Regberg,T., Stawinski,J., Stromberg,R. and Henrichson,C. (1986) Tetrahedron Lett., 27, 4055-4058. (b) Venyaminova,A.G., Gorn,V.V., Zenkova,M.A., Komarova,N.I. and Repkova,M.N. (1990) Bioorgan. Khim., 16, 914-950.

8. (a) Venyaminova,A.G., Repkova,M.N. and Maltseva,T.V. (1991) Nucleic Acids Res. Symp. Ser., 24, 263. (b) Yastrebov,S.I. (1985) Bulleten Izobreteniy, 17, 28. (c) Lokhov,S.G., Podyminogin,M.A., Sergeev,D.S., Silnikov,V.N., Kutyvin,I.V., Shishkin,G.V. and Zarytova,V.F. (1992) Bioconjugate Chem., 3, 414-419. (d) Cantor,C.R. and Tinoco,I.Jr. (1965) J. Mol. Biol., 13, 65-72.

9. Both AURELIA and SMART were supplied by Bruker. (b) Carr,H.Y. and Purcell,E.M. (1954) Phys. Rev., 94, 630

10. Liu,H., Kumar,A., Weisz,K., Schmitz,U., Bishop,K.D. and James,T.L. (1993) J. Am. Chem. Soc., 115, 1590-1591, and references therein MARDIGRAS (v.5.0) was obtained from Prof. T.L.James, UCSF, San Fransisco, CA.

11. (a) Gao,X. and Jeffs,P.W. (1994) J. Biomol. NMR, 4, 367-384. (b) Fedoroff,O.,Yu., Salazar,M. and Reid,B.R. (1993) J. Mol. Biol., 233, 509-523. (c) Fritsch,V. and Wolf,R.M. (1994) J. Biomol. Struct. Dyn., 11, 1161 - 1174. (d) Salazar,M., Fedoroff,O.,Yu., Miller,J.M., Ribeiro,N.S. and Reid,B.R. (1993) Biochemistry, 32, 4207-4215. (e) Chou,S.-H., Flynn,P. and Reid,B. (1989) Biochemistry, 28, 2435-2443. (f) Katahira,M. Lee,S.J., Kobayashi,Y., Sugeta,H., Kyogoku,Y., Iwai,S., Ohtsuka,E., BenevidesJ.M. and Thomas,G.J.,Jr (1990) J. Am. Chem. Soc., 112, 4508-4512. (g) Wang,A.C., Kim,S.G., Flynn,P.F., Chou,S.-H., Orban,J. and Reid,B.R (1992) Biochemistry, 31, 3940-3946. (k) Lane,A.N., Ebel,S. and Brown,T. (1993) Eur. J. Biochem., 215, 297-306. (m) Wang,A.H.J., Fujii,S., Van Boom,J.H., Van der Marel,G.A., Van Boeckel,C.A.A and Rich,A (1982) Nature, 299,601-604. (n) Gonz lez,C., Stec,W., Kobylanska,A., Hogrefe,R.I., Reynolds,M., and James,T.L. (1994) Biochemistry, 33, 11062-11072.

12. (a) M.de Leeuw,F.A.A. and Altona,C.(1983) J. Comp. Chem., 4, 428. (b) Rinkel,L.J. and Altona,C. (1987) J. Biomol. Struct. Dyn., 4, 621-649.

13. Kim,S.-G., Lin,L.-J. and Reid,B.R. (1992) Biochemistry, 31, 3564-3574.

14. Knorre,D.G., Vlasov,V.V., Zarytova,V.F., Lebedev,A.V. and Federova,O.S. In Design and targeted reactions of oligonucleotide derivatives. CRC press, Boca Raton, FL, 1994). 